\title{
Performance of Ternary Class F Pulverised Fuel Ash and Ground Granulated Blast Furnace Slag Concrete in Sulfate Solutions
}

\author{
John Kamau and Ash Ahmed
}

\begin{abstract}
Durability of concrete is defined as its ability to resist deterioration after it has been exposed to the environment of its intended use. This work examined the performance of combined (ternary) Pulverised Fuel Ash (PFA) and Ground Granulated Blast Furnace Slag (GGBS) concrete in sulfate solutions of sodium sulfate $\left(\mathrm{Na}_{2} \mathrm{SO}_{4}\right)$, magnesium sulfate $\left(\mathrm{MgSO}_{4}\right)$ and mixed $\mathrm{Na}_{2} \mathrm{SO}_{4}$ and $\mathrm{MgSO}_{4}$, as well as its performance in water absorption. Investigations were carried out on replacements that were found to have achieved the highest compressive strengths as well as on $30 \%$ replacements from a previous study. From the results obtained, it was also found that at highest compressive strengths, the ternary concrete could be used with an advantage over the individual binary concretes in $\mathrm{MgSO}_{4}$ environments, whereas at a higher replacement, the ternary concrete could be used with an advantage over individual binary specimens in $\mathrm{Na}_{2} \mathrm{SO}_{4}$ and $\mathrm{MgSO}_{4}$ environments. For visual observations, it was concluded that the ternary concrete could be used with an advantage over the individual binary concretes in $\mathrm{Na}_{2} \mathrm{SO}_{4}$ and $\mathrm{MgSO}_{4}$ environments, whereas for strength deterioration, the results showed that the ternary specimens could be used with an advantage over individual binary concretes in both the $\mathrm{MgSO}_{4}$ and the mixed sulfate solutions. Generally, the ternary specimens showed some complimentary effect from the two materials.
\end{abstract}

Index Terms-PFA; GGBS; Sulfate Attack, Ternary Concrete.

\section{INTRODUCTION}

Durability of concrete is defined as its ability to resist deterioration of any form, thereby allowing it to maintain its original quality and form after it has been exposed to the environment of its intended use [1].

The deterioration of concrete can be either from external attacks by chemicals or from chemical reactions from within the constituents of concrete [1]. Sulfate attack affects the durability of concrete by causing it to lose its compressive strength, and affects calcium hydroxide $\left[\mathrm{Ca}(\mathrm{OH})_{2}\right]$, a product of the early hydration of cement, and Calcium Silicate Hydrate (C-S-H), a product of the reaction between silicone dioxide $\left(\mathrm{SiO}_{2}\right)$ from $\mathrm{SCMs}$ and $\mathrm{Ca}(\mathrm{OH})_{2}$ from the hydration of cement, a reaction also known as the pozzolanic reaction [2].

Sodium sulfate $\left(\mathrm{Na}_{2} \mathrm{SO}_{4}\right)$ attacks $\mathrm{Ca}(\mathrm{OH})_{2}$ whereas Magnesium sulfate $\left(\mathrm{MgSO}_{4}\right)$ attacks $\mathrm{C}-\mathrm{S}-\mathrm{H}$, with $\mathrm{MgSO}_{4}$ attack being reported to be the most severe [2].

Published on July 11, 2017.

J. Kamau is with the Civil Engineering Group. Leeds Beckett University, Leeds, England, UK (email: John.kamau@yahoo.com)

A. Ahmed is with the Civil Engineering Group. Leeds Beckett University, Leeds, UK (email: A.R.Ahmed@ leedsbeckett.ac.uk)
$\mathrm{Na}_{2} \mathrm{SO}_{4}$ reacts with $\mathrm{Ca}(\mathrm{OH})_{2}$ to produce gypsum $\left[\mathrm{CaSO}_{4}\right.$. $2\left(\mathrm{H}_{2} \mathrm{O}\right)$ ] and/or with alluminate $\left(\mathrm{C}_{3} \mathrm{~A}\right)$ and alumina-bearing hydration products to form ettingite [3]. Gypsum and ettringite's precipitation in concrete could generate stresses within the concrete, which if greater than the tensile strength of the concrete may bring about loss in strength, expansion, spalling and degradation [2]. Literature has it therefore that $\mathrm{Na}_{2} \mathrm{SO}_{4}$ manifests and should be evaluated through expansion [2].

$\mathrm{MgSO}_{4}$ attack involves the outward diffusion of hydroxide ions to form brucite and an inwards diffusion of sulfate ions to form gypsum, a combined layer, which retards the harmful effects of $\mathrm{MgSO}_{4}$ attack in the early age [4]. Literature also has it that this layer peels off at latter ages due to the formation of expansive ettringite and gypsum, which causes cracking on the surface of the brucite layer, leading to the decomposition of C-S-H to Magnesium Silicate Hydrate (M-S-H) [2].

The non-cementitious M-S-H allows the easy diffusion of sulfate ions into the concrete matrix, and has been reported to be the major and final stage of $\mathrm{MgSO}_{4}$ attack, bringing about the reduction in strength of concrete [2]. As a result, it has been suggested that $\mathrm{MgSO}_{4}$ attack should be evaluated through the loss of strength [2], [4].

Low sulfate resistance is characterised by high levels of $\mathrm{Ca}(\mathrm{OH})_{2}$, sulfate $\left(\mathrm{SO}_{4}\right)$, iron oxide $\left(\mathrm{Fe}_{2} \mathrm{O}_{3}\right)$ and $\mathrm{C}_{3} \mathrm{~A}$; and low levels of silicone dioxide $\left(\mathrm{SiO}_{2}\right)$ [5]. A high molar ratio of sulfite $\left(\mathrm{SO}_{3}\right)$ to aluminium oxide $\left(\mathrm{Al}_{2} \mathrm{O}_{3}\right)$ enhances the formation of monosulfate, which leads to the formation of ettringite and gypsum on exposure to sulfate attack [2].

Pozzolanic reactions which result from the use of materials such as Pulverised Fuel Ash (PFA) and Ground Granulated Blast Furnace Slag (GGBS) in concrete help in mitigating the effects of $\mathrm{Na}_{2} \mathrm{SO}_{4}$ attack by refining pores, diluting $\mathrm{C}_{3} \mathrm{~A}$ and removing $\mathrm{Ca}(\mathrm{OH})_{2}$ by converting it into $\mathrm{C}$ $\mathrm{S}-\mathrm{H}$, thereby reducing the quantities of gypsum formed [2]. However, as $\mathrm{MgSO}_{4}$ mainly attacks C-S-H, a poor performance in $\mathrm{MgSO}_{4}$ solutions has been reported where pozzolanic reactions are involved [2], [4].

Permeability is the most important aspect of durability and service life of concrete structures [6]. It is measured by the ease with which a gas or liquid can get into and pass through concrete, or rate at which water under pressure can flow through interconnected voids within concrete [7]. According to [8] and [9], maintaining low permeability is more important than controlling the chemistry of cement because it inhibits the diffusivity of sulfate ions, thereby improving the durability of concrete.

The C-S-H that is formed as a result of using SCMs in 
concrete changes from fibrillary to foil like, and forms a distorted capillary pore structure, leading to lower permeability [10]. SCMs also reduce permeability through the packing effect of unreacted particles [2].

PFA is a fine residual material that results from the burning of ground and pulverised coal by power plants, whereas Ground Granulated Blast Furnace Slag (GGBS) is a by-product of pig iron manufacture in a blast furnace [11].

\section{RESEARCH SIGNIFICANCE}

There is consensus in literature that the use of PFA and GGBS improves the properties of concrete [2]. The complementary effect of PFA and GGBS when used in ternary (2 SCMs) concrete has been reported, whereby GGBS has been observed to improve the compressive strength of PFA, whereas PFA has been observed to improve the rheological behavior of GGBS [12].

The performance of PFA and GGBS in sulfate environments has also been reported [13], [14]. No work was however found on the performance of the two materials in a ternary mix in sulfate environments. Moreover, with the shutting down of old polluting coal-power stations and coal mines in the UK [15], the gradual decline in the volumes of PFA produced will call for an optimum method of its utilisation, and using it in a ternary mix with GGBS could be one way of achieving this objective.

\section{METHODS}

\section{A. Previous data and chemical composition}

The compressive strength of PFA and GGBS was investigated by [16]. Table I and Fig. 1 show the compressive strengths achieved by [16], whereas Table II shows the chemical composition of PFA and GGBS used for this study. The $0 \%$ replacement, also referred to as the control was the reference from which all performances were measured by both [16] and in this work.

TABLE I: COMPRESSIVE STRENGTHS OF BINARY AND TERNARY PFA AND GGBS $\left(\mathrm{N} / \mathrm{MM}^{2}\right)$

\begin{tabular}{ccccccccc}
\hline \hline & \multicolumn{7}{c}{7.5} \\
Specimens & $0 \%$ & $5 \%$ & $\%$ & $10 \%$ & $15 \%$ & $20 \%$ & $25 \%$ & $30 \%$ \\
\hline PFA & 71.3 & 56.7 & 55.9 & 51.0 & 54.0 & 48.7 & 50.7 & 50.5 \\
\hline GGBS & 71.3 & 53.1 & 60.3 & 61.8 & 62.6 & 61.2 & 60.7 & 54.1 \\
\hline $\begin{array}{c}\text { PFA and } \\
\text { GGBS }\end{array}$ & 71.3 & 56.8 & 61.8 & 61.2 & 60.7 & 57.3 & 53.5 & 52.7 \\
\hline \hline
\end{tabular}

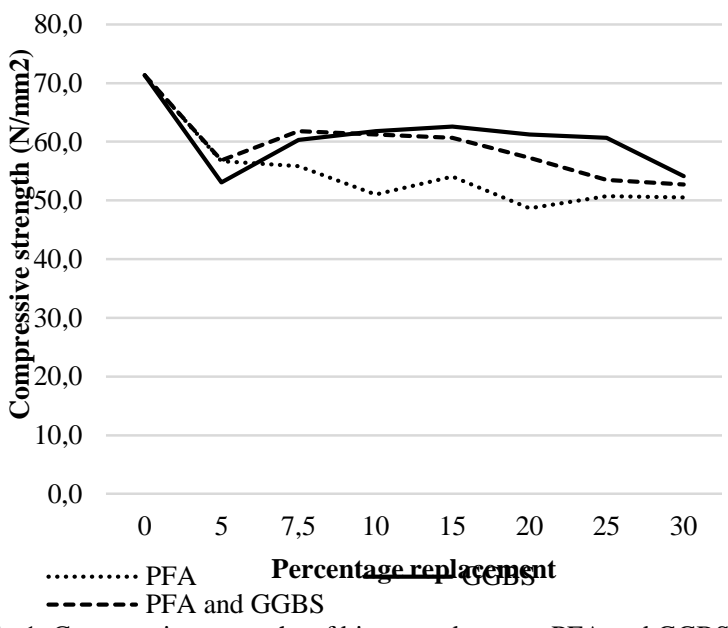

Fig.1. Compressive strengths of binary and ternary PFA and GGBS $\left(\mathrm{N} / \mathrm{mm}^{2}\right)$
TABLE II: PERCENTAge CHEMiCAL COMPOSITION OF PFA Class F AND GGBS

\begin{tabular}{lcc}
\hline \hline \multirow{2}{*}{ Chemical } & \multicolumn{2}{c}{ Percentage Composition } \\
\cline { 2 - 3 } & Class F PFA & GGBS \\
\hline Silicon dioxide $\left(\mathrm{SiO}_{2}\right)$ & 54.2 & 35.7 \\
\hline Aluminium oxide $\left(\mathrm{Al}_{2} \mathrm{O}_{3}\right)$ & 23.7 & 13.9 \\
\hline Iron oxide $\left(\mathrm{Fe}_{2} \mathrm{O}_{3}\right)$ & 7.3 & 0.3 \\
\hline Calcium oxide $(\mathrm{CaO})$ & 3.1 & 41.2 \\
\hline Magnesium oxide $(\mathrm{MgO})$ & 2.5 & 8.1 \\
\hline Sodium oxide $\left(\mathrm{Na}_{2} \mathrm{O}\right)$ & 0.6 & 0.4 \\
\hline Potassium oxide $\left(\mathrm{K}_{2} \mathrm{O}\right)$ & 4 & 0.4 \\
\hline Loss on ignition $(\mathrm{LOI})$ & 0.4 & 0.7 \\
\hline Sulphur trioxide $(\mathrm{SO})$ & 0.5 & 3.6 \\
\hline \hline
\end{tabular}

\section{B. Water absorption}

The water absorption test was conducted to [17] on two different sets of specimens. The first set was one which had achieved the highest compressive strengths from the results shown in Table I and Fig. 1 above, following the argument by [8] that durability is directly proportional to the compressive strength of concrete, whereas the second set were specimens that had been made using PFA and GGBS replacements of $30 \%$ by the weight of cement, which was the highest replacement for this research. The higher replacement was used in order to assess the effectiveness of the filler effect of unreacted particles of SCMs on the durability of concrete.

Specimens were made using $100 \mathrm{~mm}$ x $100 \mathrm{~mm}$ x 100 mm moulds. Materials used were White Portland cement (WPC), fine aggregates, coarse aggregates and water at $380 \mathrm{~kg}, 760 \mathrm{~kg}, 1140 \mathrm{~kg}$ and 180 litres per cubic meter respectively or a mix proportion of 1: $2: 3$. The preparation of cubes conformed to [18].

The apparatus were a water tank, stopwatch, ventilated oven and a weighing instrument. The test specimens were cured in water for 270 days after which they were dried to a constant mass in the ventilated oven, at a temperature of $70^{\circ} \mathrm{C}$. They were then allowed to cool down at room temperature and the dimensions to be immersed were taken confirming to [19].

The gross area was calculated and the test specimens were immersed in water to a depth of $5 \mathrm{~mm}$ for a total immersion time of 10 minutes. The results were calculated using (1) conforming to [17].

$C_{\text {w.s }}=\frac{M_{\text {so.s }}-M_{\text {dry.s }}}{A_{\text {s.t so }}} \times 10^{6}\left[\frac{\mathrm{g}}{\mathrm{m}^{2} . \mathrm{s}}\right]$

Where $\mathrm{C}_{\mathrm{w} . \mathrm{s}}$ is the coefficient for water absorption, $\mathrm{M}_{\text {so.s }}$ is the mass in grams $(\mathrm{g})$ of the specimen after soaking in water for a time ( $t), M_{d r y . s}$ is the mass in grams of the specimen after drying, $\mathrm{A}_{\mathrm{s}}$ is the gross area in $\mathrm{mm}^{2}$ of the face of the specimen immersed in water and $t_{s o}$ is the time of soaking in seconds (s).

\section{Sulfate testing}

Sulfate elongation tests conformed to [20]. Using the mix proportions discussed above, cubic prismatic concrete samples of size $160 \mathrm{~mm}$ x $40 \mathrm{~mm}$ x $40 \mathrm{~mm}$ and $100 \mathrm{~mm}$ x $100 \mathrm{~mm} \times 100 \mathrm{~mm}$ cubes were cast and placed in an oven 
for $23^{1 / 2}$ hours at $35^{0} \mathrm{C}$ after which they were removed from the container and demoulded. Two cubes were crushed to ensure that the concrete had achieved compressive strengths of not less than $20.0 \mathrm{~N} / \mathrm{mm}^{2} \pm 1.0 \mathrm{~N} / \mathrm{mm}^{2}$. The lengths of the bars were taken before they were immersed in $5 \%$ sodium sulfate $\left(\mathrm{Na}_{2} \mathrm{SO}_{4}\right), 5 \%$ magnesium sulfate $\left(\mathrm{MgSO}_{4}\right)$ and $2.5 \%+2.5 \% \mathrm{Na}_{2} \mathrm{SO}_{4}$ and $\mathrm{MgSO}_{4}$ solutions at laboratory temperatures of $23^{\circ} \mathrm{C}$. A pH of 6 to 8 was maintained on the sulfate solutions throughout the testing period.

Lengths were measured at weeks $1,2,3,4$, and 8 , and at 4, 8, and 9 months conforming to [20]. Lengths were measured using veneer calipers.

Readings were taken as an average of three bars and three cubes for elongation and strength deterioration tests respectively conforming to [20].

Like water absorption tests, elongation tests were carried out on two different sets of specimens. The first set were specimens that had achieved the highest compressive strengths from Table I above, whereas the second set were specimens that had been made with PFA and GGBS replacements of $30 \%$ by the weight of cement.

Length changes were worked out using (2) conforming to the American Society for Testing and Materials [20].

$\Delta \mathrm{L}=\frac{L x-L i}{L g} \times 100$

Where:

$\Delta_{\mathrm{L}}=$ percentage change in length at age of measuring,

$\mathrm{L}_{\mathrm{x}}=$ Veneer calipers reading of specimen at age of measuring,

$\mathrm{L}_{\mathrm{i}}=$ Veneer calipers reading of specimen on immersion,

$\mathrm{L}_{\mathrm{g}}=160$ (nominal length between the innermost ends of the moulds used).

Visual observation for surface deterioration was done at the end of immersion (270 days).

Compressive strength deterioration was assessed using the method employed by [4], who studied deterioration from sulfate attack on cube specimens by measuring the Strength Deterioration Factor (SDF). The SDF was worked out using (3) after [4].

$S D F=\frac{f_{c w^{\prime}}-f_{C S^{\prime}}}{f_{c w^{\prime}}} X 100$

Where $f_{c w}$, is the compressive strength of cube specimens immersed in the control solution and $\mathrm{f}_{\mathrm{cs}}$, is the compressive strength of sulfate immersed specimen cubes.

\section{RESUlTS AND DisCUSSION}

\section{A. Water absorption}

Table III and Fig. II represent results of the coefficient of water absorption $\left(\mathrm{C}_{\mathrm{w} . \mathrm{s}}\right)$ in grams. A standard deviation of $0.02 \mathrm{C}_{\mathrm{w} . \mathrm{s}}$ was calculated across the range of tests. Results showed that at highest compressive strengths, both ternary and binary PFA and GGBS-replaced specimens showed lower coefficients of water absorption than those of the control specimens, with the ternary specimens showing a higher performance than that of PFA but lower than GGBSreplaced specimens.
For highest replacement levels, ternary and binary specimens of PFA and GGBS also showed lower coefficients of water absorption than those of the control, even though the performances were significantly reduced compared with those of replacements at highest compressive strengths. At highest replacement, the performance of the ternary specimens was lower than that of PFA but higher than that of GGBS specimens.

From the findings of this work, the permeability of the ternary GGBS and PFA specimens appeared to increase with increased replacement. GGBS seemed to reduce the permeability of PFA at the lower replacement, whereas PFA appeared to reduce that of GGBS at the higher replacement, consistent with [12] that SCMs used together in mixes improve each other's properties.

TABLE III: COEFFICIENT OF WATER ABSORPTION OF BINARY AND TERNARY PFA AND GGBS [CW.S (G/M $\left.{ }^{2} . \mathrm{S}\right)$ ]

\begin{tabular}{cccc}
\hline \hline \multicolumn{2}{c}{ Highest compressive strength } & \multicolumn{2}{c}{ Highest replacement } \\
\hline \hline Specimens & Cw.s $\left(\mathrm{g} / \mathrm{m}^{2} . \mathrm{s}\right)$ & Specimens & $\begin{array}{c}\text { Cw.s } \\
(\mathrm{g} / \mathrm{m} 2 . \mathrm{s})\end{array}$ \\
\hline Control & 0.5767 & Control & 0.5767 \\
\hline $5 \%$ PFA & 0.4383 & $30 \%$ PFA & 0.5008 \\
\hline $15 \%$ GGBS & 0.4283 & $30 \%$ GGBS & 0.5425 \\
\hline $3.75 \%$ PFA + & & $15 \%$ PFA + & \\
$3.75 \%$ GGBS & 0.4333 & $15 \%$ GGBS & 0.5350 \\
\hline \hline
\end{tabular}

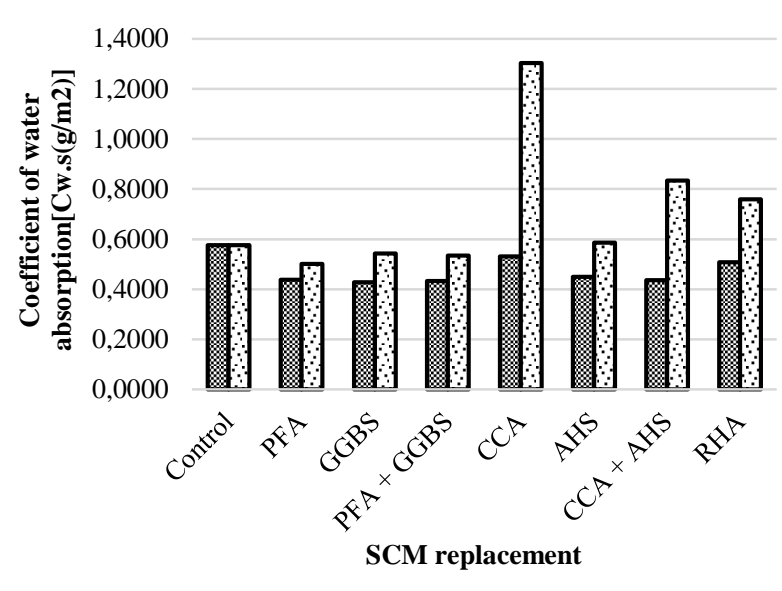

$\boldsymbol{\otimes}$ Highest compressive strength $\boldsymbol{\square}$ Highest replacement

Fig. 2. Coefficient of water absorption of binary and ternary PFA and GGBS $\left[\mathrm{C}_{\mathrm{w} . \mathrm{s}}\left(\mathrm{g} / \mathrm{m}^{2} . \mathrm{s}\right)\right]$

\section{B. Sulfate tests}

Tables IV and Fig. 3 and Table V and Fig. 4 show the percentage expansion of binary and ternary specimens of PFA and GGBS at highest compressive strengths and at $30 \%$ replacements respectively. For the highest compressive strengths, ternary PFA and GGBS-replaced specimens performed better than the control and the PFA but worse than GGBS specimens in the $5 \% \mathrm{Na}_{2} \mathrm{SO}_{4}$ solution.

At highest replacement, the ternary specimens performed better than the control and individual binary specimens. The expansions at the $30 \%$ replacement were however higher than those at highest compressive strengths for all the specimens.

Veiga and Gastaldini [13] attributed the high sulfate attack resistivity of GGBS to the consumption of $\mathrm{Ca}(\mathrm{OH})_{2}$ by the pozzolanic reaction, and the reduction of the ratio of $\mathrm{CaO}$ to $\mathrm{SiO}_{2}$. Veiga and Gastaldini [13] however reported an increase in sulfate resistance with increased GGBS 
replacement contrary to the findings of this work.

Even though [2] posited that the filler effect by unreacted particles of SCMs is one of the factors that limit gypsum and the secondary formation of ettringite by reducing the permeability of concrete, a higher permeability at higher replacements was attributed by [1] to reduced levels of $\mathrm{Ca}(\mathrm{OH})_{2}$ available to react with excess SCMs to form the foil like $\mathrm{C}-\mathrm{S}-\mathrm{H}$, which results in a less well-interconnected capillary pore structure. This leads to the creation of pores and consequently the easy diffusion of sulfate ions [1].

The ability of PFA, GGBS, and ternary PFA and GGBSreplaced specimens to resist expansion can be attributed to the reduction in the content of alite $\left(\mathrm{C}_{3} \mathrm{~S}\right)$ and aluminate $\left(\mathrm{C}_{3} \mathrm{~A}\right)$ [2]. The good performance of PFA and GGBS at highest compressive strengths in the $\mathrm{Na}_{2} \mathrm{SO}_{4}$ environment can also be attributed to the low molar ratio of $\mathrm{SO}_{3}$ to $\mathrm{Al}_{2} \mathrm{O}_{3}$, which according to [2] contributes to higher sulfate resistance at lower replacements.

As was discussed before, low permeability is important because it inhibits the diffusivity of sulfate ions, ultimately improving the durability of concrete [6]. From Table III and Fig. 2, it was found that specimens at the $30 \%$ replacement had higher coefficients of water absorption compared with replacements at highest compressive strengths. As a result, [8] and [6]'s assumption that durability is directly proportional to the compressive strength of concrete seems to be plausible.

TABLE IV: PERCENTAGE ElONGATION AT Highest COMPRESSIVE STRENGTHS

\begin{tabular}{lccc}
\hline \hline \multirow{2}{*}{ Specimens } & \multicolumn{3}{c}{ Percentage elongation at 270 days } \\
\cline { 2 - 4 } & & & \multicolumn{2}{c}{$\begin{array}{l}\mathrm{Na}_{2} \mathrm{SO}_{4} \\
\text { and } \\
\mathrm{MgSO}_{4}\end{array}$} \\
\hline Control & 0.0937 & 0.0219 & 0.0750 \\
\hline PFA & 0.0375 & 0.0188 & 0.0338 \\
\hline GGBS & 0.0125 & 0.0088 & 0.3625 \\
\hline PFA and GGBS & 0.0240 & 0.0080 & 1.4188 \\
\hline \hline
\end{tabular}

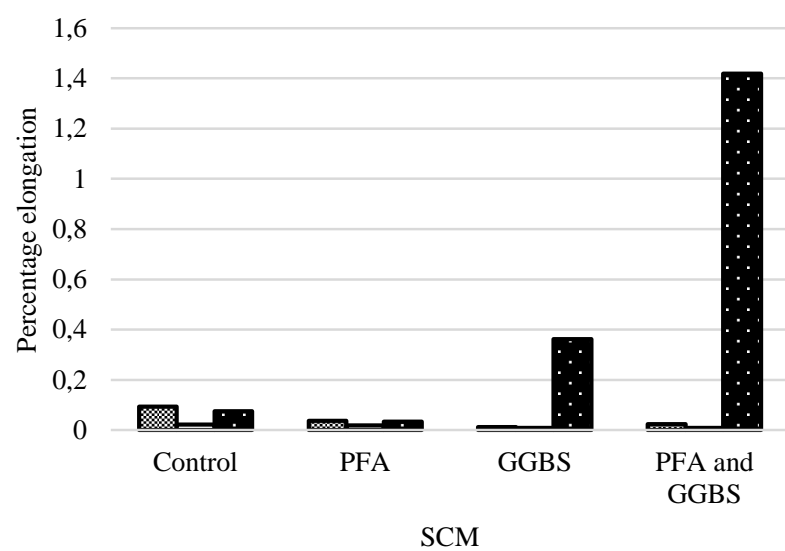

$\boldsymbol{\otimes}$ Sodium sulfate $\mathbf{\square}$ Magnesium sulfate $\mathbf{D}$ Mixed sulfate solution

Fig.3. Percentage elongation at highest compressive strengths

TABle V: Percentage Elongation in Sulfate Solutions at 30\% REPLACEMENT

\begin{tabular}{lccc}
\hline \hline Specimens & \multicolumn{3}{c}{ Percentage elongation at 270 days } \\
\hline & $\mathrm{Na}_{2} \mathrm{SO}_{4}$ & $\mathrm{MgSO}_{4}$ & $\begin{array}{c}\mathrm{Na}_{2} \mathrm{SO}_{4} \text { and } \\
\mathrm{MgSO}_{4}\end{array}$ \\
\hline Control & 0.4850 & 0.1875 & 0.3500 \\
\hline GGBS & 0.2500 & 0.3542 & 0.7542 \\
\hline
\end{tabular}

\begin{tabular}{llll} 
PFA & 0.2292 & 0.3083 & 0.6375 \\
\hline PFA and GGBS & 0.0792 & 0.2708 & 0.7917 \\
\hline \hline
\end{tabular}

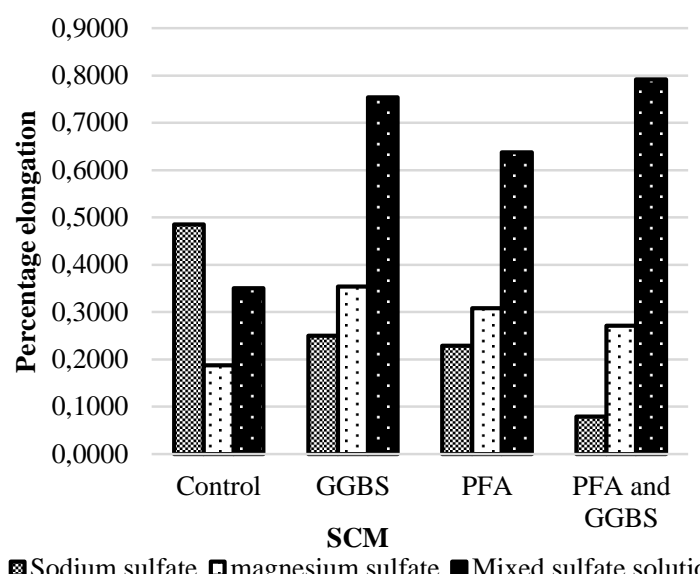

Fig. 4. Percentage elongation in sulfate solutions at $30 \%$ replacement

At highest compressive strengths in the $\mathrm{MgSO}_{4}$ solution, the performance of the ternary PFA and GGBS specimens were above those of the control and binary specimens at the highest compressive strengths. The expansions were however negligible consistent with literature that $\mathrm{MgSO}_{4}$ attack does not manifest itself through expansion [2].

The low expansions in the $\mathrm{MgSO}_{4}$ solution were attributed by [4] to the lower alkalinity that is associated with the formation of brucite in the cement matrix due to the presence of magnesium ions. However, at the highest replacement level, even though the ternary specimens were above those of the binary specimens in the $\mathrm{MgSO}_{4}$ solution, they were below those of the control specimens, calling into question previous research that $\mathrm{MgSO}_{4}$ attack only manifests itself through the loss of strength of the concrete and not expansion [2].

In the mixed sulfate solution, the ternary specimens performed poorly compared with the individual binary and control specimens at both highest compressive strengths and $30 \%$ replacement.

Consistent with [4], the findings of this work showed a higher resistance for the control specimens than those of binary and ternary specimens of PFA and GGBS in solutions that contained $\mathrm{MgSO}_{4}$, and especially at the $30 \%$ replacement. As has already been discussed, the reaction between $\mathrm{MgSO}_{4}$ and $\mathrm{Ca}(\mathrm{OH})_{2}$ produces the insoluble brucite, which blocks capillary pores, forming a sulfate impermeable layer [2], [4]. However, since SCMs contain less $\mathrm{Ca}(\mathrm{OH})_{2}$ and more $\mathrm{C}-\mathrm{S}-\mathrm{H}, \mathrm{MgSO}_{4}$ readily reacts with the secondary $\mathrm{C}-\mathrm{S}-\mathrm{H}$ gel to form $\mathrm{M}-\mathrm{S}-\mathrm{H}$ gel once the combined layer of gypsum and brucite has peeled off, which explains the superiority of the control specimens over SCMs in solutions that contained $\mathrm{MgSO}_{4}$ [4].

$\mathrm{M}-\mathrm{S}-\mathrm{H}$ is not cementitious and it results in the softening of the cement matrix [5]. This alteration of C-S-H to M-S-H was termed by [2] as probably the final stage of deterioration of concrete under $\mathrm{MgSO}_{4}$ attack.

These findings show that at highest compressive strengths, the ternary concrete of PFA and GGBS could be used with an advantage over the individual binary concretes in $\mathrm{MgSO}_{4}$ environments and PFA concrete in $\mathrm{Na}_{2} \mathrm{SO}_{4}$ environments, whereas at the $30 \%$ replacement, the ternary 
concrete of PFA and GGBS could be used with an advantage over individual binary specimens in $\mathrm{Na}_{2} \mathrm{SO}_{4}$ and $\mathrm{MgSO}_{4}$ environments.

\section{Surface deterioration}

Table VI shows the surface deterioration of binary and ternary specimens of PFA and GGBS at the end of immersion in sulfate solutions after [21].

TABLE VI: VISUAL OBSERVATIONS OF SURFACE DETERIORATION OF SPECIMENS IMMERSED IN SULFATE SOLUTIONS AFTER [21]

\begin{tabular}{lccc}
\hline \hline Specimen & $5 \% \mathrm{Na}_{2} \mathrm{SO}_{4}$ & $5 \% \mathrm{MgSO}_{4}$ & $\begin{array}{c}2.5 \% \\
\mathrm{Na}_{2} \mathrm{SO}_{4} \\
+2.5 \% \\
\mathrm{MgSO}_{4}\end{array}$ \\
\hline Control & 0 & 0 & 2 \\
\hline PFA & 0 & 1 & 2 \\
\hline GGBS & 0 & 1 & 2 \\
\hline $50 \%$ PFA & 0 & 0 & 2 \\
$\begin{array}{l}\text { and } \\
50 \% \text { GGBS }\end{array}$ & & & \\
\hline \hline
\end{tabular}

Key: Deterioration levels. 0, no damage; 1, minimum visible cracks; 2, mass loss and some disintegration; 3 , extensive spalling and softening; 4, wider cracks and extensive spalling; 5, Complete disintegration

Surface deterioration observed at the end of the immersion period showed that similar with the control specimens, the ternary specimens of PFA and GGBS showed no surface deterioration in the $\mathrm{Na}_{2} \mathrm{SO}_{4}$ and $\mathrm{MgSO}_{4}$ solutions. However, they showed mass loss and some disintegration also similar to the control specimens in the mixed sulfate solution. On the other hand, even though the binary specimens did show the same kind of deterioration as the ternary specimens in the mixed sulfate solution and no deterioration in the $\mathrm{Na}_{2} \mathrm{SO}_{4}$ solution, they also showed some visible cracks in the $\mathrm{MgSO}_{4}$ solution.

Consistent with [2], the most severe effects of sulfate attack were observed in solutions that contained $\mathrm{MgSO}_{4}$. Also in agreement with [2], [4], the inferiority of specimens immersed in the mixed sulfate solution to those immersed in the individual solutions of $\mathrm{Na}_{2} \mathrm{SO}_{4}$ and $\mathrm{MgSO}_{4}$ spelled the predominance of the more aggressive $\mathrm{MgSO}_{4}$ attack over $\mathrm{Na}_{2} \mathrm{SO}_{4}$ attack. $\mathrm{MgSO}_{4}$ is highly soluble in water at room temperature $\left(20^{\circ} \mathrm{C}\right)$ compared to $\mathrm{Na}_{2} \mathrm{SO}_{4}$ [4]. Moon, et al. [4] further posited that the presence of brucite and gypsum for $\mathrm{SCM}$ specimens immersed in the $\mathrm{MgSO}_{4}$ solution was the cause of surface deterioration.

Unlike [4] who reported that the control specimens showed visible cracks and spalling in the $\mathrm{Na}_{2} \mathrm{SO}_{4}$ solution, no surface deterioration was observed on the control specimens in the $\mathrm{Na}_{2} \mathrm{SO}_{4}$ solution. The good performance of the control specimens is consistent with [13], who reported that mortars with White Portland Cement (WPC) showed higher resistivity to sulfate attack, a factor which could be attributed to the additional $5 \%$ to $10 \%$ coloring pigment [5], which could in turn reduce the levels of $\mathrm{Ca}(\mathrm{OH})_{2}$ produced during the hydration of cement.

The findings on surface deterioration show that the ternary concrete of PFA and GGBS could be used with an advantage over the individual binary concretes in $\mathrm{Na}_{2} \mathrm{SO}_{4}$ and $\mathrm{MgSO}_{4}$ environments.

\section{Strength deterioration}

As earlier on stated, strength deterioration was assessed using the Strength Deterioration Factors (SDFs) after [4]. Table VII shows the SDFs of binary and ternary specimens of PFA and GGBS immersed in $\mathrm{Na}_{2} \mathrm{SO}_{4}, \mathrm{MgSO}_{4}$ and mixed sulfate solutions. From the results, the ternary specimens' performance in the $\mathrm{Na}_{2} \mathrm{SO}_{4}$ solution was below that of binary GGBS but higher than both the control and PFA specimens, whereas in the $\mathrm{MgSO}_{4}$ and mixed sulfate solutions, the ternary specimens' SDF was lower than the control and the binary specimens.

As has already been discussed, the poor performances of SCMs in the $\mathrm{MgSO}_{4}$ solution compared to the $\mathrm{Na}_{2} \mathrm{SO}_{4}$ solution were attributed to the formation of insoluble brucite $\left[\mathrm{Mg}(\mathrm{OH})_{2}\right]$, which destabilises and destroys the C-S-H gel to form the noncementitious $\mathrm{M}-\mathrm{S}-\mathrm{H}$, that results in the softening of the cement matrix [2].

TABLE VII STRENGTH DETERIORATION FACTORS (SDFS) OF SPECIMENS IN SULFATE SOLUTIONS

\begin{tabular}{ccccc}
\hline \hline & & $15 \%$ & & $15 \%$ PFA + \\
& Control & GGBS & 5\% PFA & $15 \%$ GGBS \\
\hline $5 \% \mathrm{Na}_{2} \mathrm{SO}_{4}$ & 8.6 & -4.8 & -9.2 & -5.0 \\
\hline $5 \% \mathrm{MgSO}_{4}$ & 17.7 & 10.3 & 14.3 & 9.8 \\
\hline $2.5 \%$ & & & & \\
$\mathrm{Na}_{2} \mathrm{SO}_{4}+$ & & & & \\
$2.5 \%$ & & 19.9 & 10.4 & 10.3 \\
$\mathrm{MgSO}_{4}$ & 26.9 & & & \\
\hline \hline
\end{tabular}

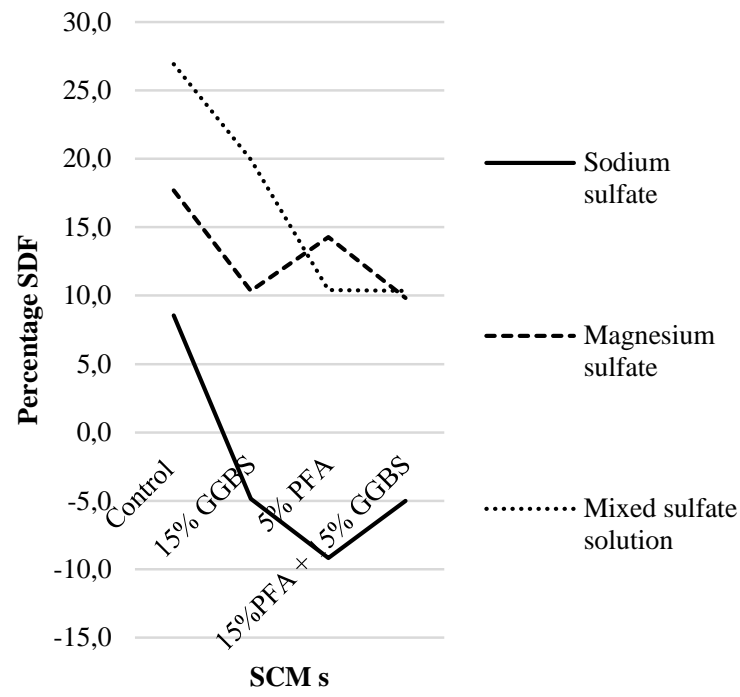

Fig.5. Strength Deterioration Factors (SDFs) of specimens in sulfate solutions

The performance of the ternary specimens on strength deterioration in both the $\mathrm{MgSO}_{4}$ and the mixed sulfate solution shows that the ternary concrete could be used in these environments with an advantage over the individual binary concretes. Ternary concrete could also be used with an advantage over PFA concrete in $\mathrm{Na}_{2} \mathrm{SO}_{4}$ environments.

\section{CONCLUSION}

This work investigated the performance of PFA and GGBS ternary concrete in sulfate solutions. The following conclusions were derived from the findings:

1. From elongation tests, at highest compressive strengths, the ternary concrete of PFA and GGBS could be used with an advantage over the 
individual binary concretes in $\mathrm{MgSO}_{4}$ environments and over PFA concrete in $\mathrm{Na}_{2} \mathrm{SO}_{4}$ environments, whereas at the $30 \%$ replacement, the ternary concrete of PFA and GGBS could be used with an advantage over individual binary concretes in $\mathrm{Na}_{2} \mathrm{SO}_{4}$ and $\mathrm{MgSO}_{4}$ environments.

2. From surface deterioration, the ternary concrete of PFA and GGBS could be used with an advantage over the individual binary concretes in $\mathrm{Na}_{2} \mathrm{SO}_{4}$ and $\mathrm{MgSO}_{4}$ environments.

3. From the strength deterioration tests, the ternary concrete could be used in the $\mathrm{MgSO}_{4}$ and the mixed sulfate environments with an advantage over the individual binary concretes. It could also be used with an advantage over PFA in the $\mathrm{Na}_{2} \mathrm{SO}_{4}$ environments.

\section{REFERENCES}

[1] [1] D. Adesanya and A. Raheem, "A study of the permeability and acid attack of corn cob ash blended cements," Construction and Building Materials, vol. 24, pp. 403-409, 2010.

[2] [2] J. D. Bapat, Mineral admixtures in cement and concrete: CRC Press, 2012.

[3] [3] M. Santhanam, M. D. Cohen, and J. Olek, "Mechanism of sulfate attack: a fresh look: Part 2. Proposed mechanisms," Cement and Concrete Research, vol. 33, pp. 341-346, 2003.

[4] [4] H.-Y. Moon, S.-T. Lee, and S.-S. Kim, "Sulphate resistance of silica fume blended mortars exposed to various sulphate solutions," Canadian Journal of Civil Engineering, vol. 30, pp. 625-636, 2003.

[5] [5] M. Shetty, Concrete technology: theory and practice: S. Chand. ISBN 8121900034, 2005.

[6] [6] A. M. Neville and J. J. Brooks, Concrete technology. Longman Scientific and Technical. ISBN 0-582-988594, 1987.

[7] [7] T. C. Holland, Silica fume user's manual: Federal Highway Administration, Silica Fume Association (SFA) Washington, 2005.

[8] [8] C. Arya, Design of structural elements: concrete, steelwork, masonry and timber designs to British standards and Eurocodes. Spon Press, LONDON AND NEW YORK: Taylor \& Francis, 2009.

[9] [9] P. Mehta, "Sulfate attack on concrete--a critical review," Mater. Sci. Concr., IIIpp., vol. 105, 1992.

[10] [10] I. Richardson, "The nature of the hydration products in hardened cement pastes," Cement and Concrete Composites, vol. 22, pp. 97$113,2000$.

[11] [11] British Standards Institution, "BS EN 197-1:2000. Part 1. Cement composition, specifications and conformity criteria for common cements. British Standards Institution (BSI), London, UK," in BSOL, ed, 2000.

[12] [12] M. Nehdi, M. Pardhan, and S. Koshowski, "Durability of selfconsolidating concrete incorporating high-volume replacement composite cements," Cement and Concrete Research, vol. 34, pp. 2103-2112, 2004.

[13] [13] K. Veiga and A. Gastaldini, "Sulfate attack on a white Portland cement with activated slag," Construction and Building Materials, vol. 34, pp. 494-503, 2012.

[14] [14] J. D. Mathews, "Performance of pfa concrete in aggressive environments, 2: Marine conditions. Building Research Establishment Laboratory Reports," 1995.

[15] [15] CarbonBrief. (2016, 22.4.2016). Analysis: UK emissions fall again after record drop in coal use in 2015. Available: http://www.carbonbrief.org/analysis-uk-emissions-fall-again-afterrecord-drop-in-coal-use-in-2015

[16] [16] J. Kamau, A. Ahmed, P. Hirst, and J. Kangwa, "Performance of Class F Pulverised Fuel Ash and Ground Granulated Blast Furnace Slag in Ternary Concrete Mixes," EJERS, European Journal of Engineering Research and Science, vol. Vol.2, 6, June 20172017.

[17] [17] British Standards Institution, "BS EN 772-11:2011. Methods of test for masonry units Part 11: Determination of water absorption of aggregate concrete, autoclaved aerated concrete, manufactured stone and natural stone masonry units due to capillary action and the initial rate of water absorption of clay masonry units. BSI, London, UK," ed, 2011.

[18] [18] British Standards Institution, "BS EN 12390-2:2009. Making and curing specimens for strength tests. BSI, London, UK," ed, 2009.

[19] [19] British Standards Institution, "BS EN 772-16:2011. Methods of test for masonry units Part 16: Determination of dimensions. BSI, London, UK," ed, 2011.

[20] [20] American Society for Testing and Materials, "ASTM C1012/C1012M-15. Standard Test Method for Length Change of Hydraulic-Cement Mortars Exposed to a Sulfate Solution1. 100 Barr Harbor Drive, PO Box C700, West Conshohocken, PA 19428-2959. United States," ed, 2015

[21] [21] O. S. B. Al-Amoudi, M. Maslehuddin, and M. M. Saadi, "Effect of magnesium sulfate and sodium sulfate on the durability performance of plain and blended cements," ACI Materials Journal, vol. 92, pp. 15-24, 1995.

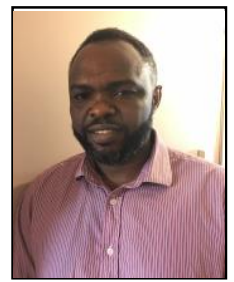

J. Kamau, the main author was born in Kenya. He graduated with a Bachelor of Science with honors degree in civil engineering from Leeds Beckett University, Leeds, West Yorkshire, United Kingdom (UK) in 2010 and a Master of Science degree in structural engineering from the University of Leeds, Leeds, West Yorkshire, UK in 2011. He is currently undertaking a research programme on supplementary cementitious materials at the Leeds Beckett University, Leeds, West Yorkshire, UK.

He has worked in the past as a CIVIL ENGINEER and is currently working as a STRUCTURAL ENGINEER in Barnsley, South Yorkshire, UK. His publications include "VIABILITY OF USING CORNCOB ASH AS A POZZOLAN IN CONCRETE (2016) -ijset, "PROPERTIES OF CONVENTIONAL CEMENT AND THIN LAYER MORTARS (2016)-ijeset and "Suitability of Corncob Ash as a Supplementary Cementitious Material (2016) - ijmse. His research interests are in the sustainability of construction materials.

Mr. Kamau is a Graduate Member of the Institution of Civil Engineers (GMICE).

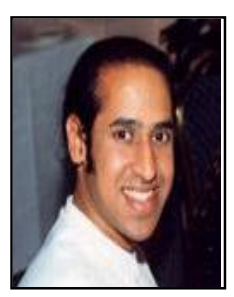

A. Ahmed, was born in Manchester, UK. He graduated with a Bachelor of Science with honors degree in Materials Science from Manchester University, United Kingdom (UK) and a Master of Philosophy degree in Metallurgy from the University of Manchester, UK. He then completed his PhD in Polymer Science from Heriot-Watt University, Edinburgh, UK.

$\mathrm{He}$ has been a Senior Lecturer at Leeds Beckett University since 2005 , teaching modules in materials science at undergraduate and postgraduate levels. Previously Head of Civil Engineering. His publications "VIABILITY OF USING CORNCOB ASH AS A POZZOLAN IN CONCRETE (2016) -ijset, "PROPERTIES OF CONVENTIONAL CEMENT AND THIN LAYER MORTARS (2016)ijeset and "Suitability of Corncob Ash as a Supplementary Cementitious Material (2016) - ijmse. His area of research is in the field of sustainable construction materials using recycled and waste products. 